\title{
Price and output effects of Monetary policy in Low Income Countries: The Case of Nepal
}

\author{
Nanda Kumar Dhakal \\ Deputy Director, Nepal Rastra Bank, Kathmandu, Nepal \\ Mitra Prasad Timsina \\ Assistant Director, Nepal Rastra Bank, Kathmandu, Nepal
}

\begin{abstract}
This paper examines the impact of monetary policy on economic growth and inflation in Nepal. The impact on economic growth and inflation have been observed using monetary policy instruments/indicators such as CRR, bank rate, interbank rate, M1, M2, private sector credit based on quarterly data from first quarter of 2006 to fourth quarter of 2018 . The impact on economic growth and inflation rate has been examined separately. The econometric methods like ADF test, ARDL Model, Bound Test, Error Correction Model, Residual Test and Stability test have been used in the study. The empirical results show that economic growth and inflation are influenced by monetary policy. CRR, bank rate, broad money and private sector credit are significant to have impact on economic growth. Likewise, money supply (M1 and M2) has impact on inflation. The result shows that it takes longer time to have impact of broad money and private sector credit on economic growth than on inflation.
\end{abstract}

Key Words: Monetary Policy, Economic Growth, Inflation, ARDL Model.

\section{INTRODUCTION}

Maintaining price stability and stabilization of output around its potential level with the effective implementation of monetary policy is among the major mandates for the central bank in most countries. A central bank formulates and implements monetary policy using money supply, interest rate and other relevant instruments in order to control price level and facilitate output growth. It is also a common practice to evaluate the performance of central bank based upon the capacity to achieve those mandated goals. In this sense, it is crucial for a central bank to measure the price and output effects of monetary policy. Besides, it is a prime responsibility of a central bank to evaluate performance and make necessary reforms in policy practices accordingly. Highlighting the importance of this task of central bank, Mishkin (1995) says evaluating the effect of monetary policy on the economy is crucial for successfully conducting it [1]. However, the response of the economy to the monetary policy actions may vary country to country depending on the financial structures (Friedman and Woodford 2010)[2], status of economic development (Mishra, Montiel and Spilimbergo, 2010) [3] and operating procedure of monetary policy (Walsh, 2010)[4]. Moreover, the degree of policy impact on the economy is also determined by the mandate for central bank to work with single goal or multiple goals. 
It is general consensus of central bankers and economists that the main objective of central banks is to ensure price stability. To attain that goal, a variety of monetary policy frameworks are developed depending on country specific policy environment. The recent development is the shifting over to the forms of inflation targeting mainly in advanced countries. Even in case of developing and countries without an explicit inflation target, there is often a strong commitment to an implicit medium-term inflation target. Moreover, countries that have fixed exchange rate systems often aim to achieve a similar inflation rate with the currencies they are pegged. In fact, there is no empirical literature having strong support to justify that abandoning price-stability would raise growth or improve welfare (Issing, 2000)[5]. Instead, there are many convincing empirical evidences that price stability is regarded as a prerequisite for sustainable output growth. Many of them have measured the price and output effects of monetary policy on the basis of three basic elements: magnitude of effect, duration of effect (time lag) and transmission channel.

Mohanty (2012) examined the impact of the change in monetary policy rate on output growth and inflation of India relying on interest rate channel. Using a structural vector auto regression (SVAR) model on quarterly data for 2001:Q1 to 2012:Q4, the study concluded that the increase in policy rate has a negative effect on output growth with a lag of two quarters and impact on inflation moderates with a lag of three quarters. The overall impact persists through 8-10 quarters [6].

Vonnak (2005) estimated the effect of monetary policy on output and prices in Hungarian economy using VAR model. To estimate the results, the paper applied two identification approaches: sign restrictions on impulse responses and imposing restrictions on implied shock history. By the two different approaches, similar results have been found. However, imposing restrictions on history may help to dampen counterintuitive reaction of prices. It is also found that, after 1995, an unanticipated monetary policy contraction resulted in an immediate 1 percent appreciation of the nominal exchange rate, followed by a 0.3 percent lower output and 0.1-0.15 percent lower consumer prices. Furthermore, the impact of monetary policy on prices is slower than on output [7].

In order to examine the impact of monetary policy shocks on output and inflation in Pakistan, Choudhri et.al. (2015) applied VAR and DSGE models. Based on conventional VAR analysis, the paper explored that monetary policy shock to have an insignificant impact on output and inflation. The researchers predicted that the frictions in the credit and foreign exchange markets in Pakistan might have diminish the transmission of monetary policy effects. However, the DSGE model that incorporates such friction indicates that they do not sufficiently weaken the effect of monetary policy shocks to explain the VAR results. Likewise, it has also been inferred that the VAR estimates understate the impact of monetary policy because of misidentification of the monetary shock [8].

Using an unrestricted Vector Auto Regression (VAR) technique, Younus examined relative effectiveness of the monetary transmission channels in Bangladesh for the sample period from 2004.M7 to 2016.M1. The paper found that both money supply and the policy rates have significant impact on output and the price level in Bangladesh. The GDP growth increase with the increase in money supply as shown by the variance decompositions and impulse response functions derived from VAR. Likewise, an increase in the policy rate decreases inflation and decreases GDP growth. Furthermore, the transmission channels through the real exchange rate increase exports, which in turn increase output [9]. 
Dhakal, N. K., \& Timsina, M. P. (2020) Price and output effects of Monetary policy in Low Income Countries: The Case of Nepal. Advances in Social Sciences Research Journal, 7(5) 478-495.

Vinayagathasan (2013) estimated the impact of the domestic and foreign monetary policy shocks and oil price shocks on Sri Lankan economic activities using SVAR model based on monthly data covering the period from January 1978 to December 2011. The study found that the interest rate shocks play a significant and better role in explaining the movement of economic variables than monetary aggregate shocks or exchange rate shocks. Likewise, it has also found that the targeting of reserve money is a better strategy for the Sri Lankan economy than a focus on narrow or broad money. Furthermore, foreign monetary policy shocks and oil price shocks do not seem to affect the domestic economy [10].

Some empirical literature examined money-price relationship in the context of Nepal. NRB (2001) estimated money-price relationship in Nepal on quarterly data from 1975Q3-1999Q2 by using OLS. The estimates show some basic conclusions that: (i) the impact of money supply on price falls in six months' time lag, (ii) the impact of money supply on price is distributed up to the third quarter, (iii) 10 percent changes in M1 would bring about 4.6 percent changes in prices, (iv) M1 has relatively stronger relationship than that of M2 with prices in Nepal and (v) money supply and inflation have a positive but week relationship [11].

Khatiwada (2005) assessed the monetary policy of Nepal using OLS method. The study found that the role of money in explaining inflation decreased whereas the role of exchange rate to explain inflation increased significantly in liberalization period (1986-2004) than pre-liberalization period (1966-1985). It is also revealed from the money price lagged relationship that the effect of money on prices begins from the second month of monetary expansion; it remains in peak during five to six month and declines thereafter [12].

By applying OLS, IMF (2014) estimated the determinants of Nepalese inflation on the monthly series of Nepal's CPI, Indian CPI, broad money and nominal effective exchange rate (NEER). The study found that change in broad money has limited impact on inflation. The 1 percent increase in broad money increases inflation by 0.12 percent whereas 1 percent increases in Indian Inflation corresponds to 0.45 percent Nepal's inflation [13]. Using ARDL model, Shrestha and Bhatta (2018) found similar conclusion on monthly data from 2000:01 to 2017:12. The study found that 1 percent increase in money supply increases the consumer price index by 0.19 percent whereas 1 percent increases in Indian consumer price index increases Nepal's CPI by 0.61 percent. However, the estimates for the split data subset show that money-price relationship in Nepal has become much stronger in the recent times whereas the impact of Indian inflation on Nepal's inflation has declined [14].

This paper attempts to analyze the impact of monetary policy on inflation and growth in the economy of Nepal. Nepal is a landlocked country surrounded by world's emerging economies India and China. It is a low income economy having with economy size of USD 30 billion and nominal per capita GDP USD 1085. Nepal has adopted full convertibility of its currency in current account whereas partial convertibility in capital accounts transactions. Also, Nepalese Currency is pegged with Indian currency since 1960. The exchange rate of Nepalese Rupees versus Indian Rupees (1.6:1) has remained unchanged since 1993. 


\section{Pre 2002}

\section{MONETARY POLICY IN NEPAL}

Nepal Rastra Bank (NRB), the central bank, was established in 1956 in Nepal as per provision of NRB Act, 1955. The major objectives of NRB establishment were to (a) ensure proper management for the issue Nepalese currency notes and its circulation throughout the country, (b) to stabilize the exchange rates of the Nepalese currency, (c) to mobilize capital for development and encourage trade and industry, and (d) to develop the banking system in Nepal.

After 10 years of NRB establishment, it realized need of monetary and credit policies. The basic objectives of monetary and credit policies were to foster economic growth, generate employment, contain prices, promote healthy balance of payments of the country. In 1966, NRB introduced cash reserve ratio, a monetary policy instrument. Along with this, instruments such as credit control regulations, interest rate administration, margin rates and refinance rate were introduced in 1960s, and liquidity requirements, credit limits /ceilings and directed credit programmes in 1970s.

Nepal Rastra Bank adopted direct approach of monetary policy implementation until late 1980s. Since then, it gradually adopted market based strategy and indirect instruments of monetary policy. These approaches and strategies included open market operation, interest rate deregulation etc.

Table 1: Introduction of Monetary Policy Instruments

(Prior to 2002)

\begin{tabular}{|c|c|}
\hline Policy Instrument & Year \\
\hline Directives issued for BFIs. & 1966 \\
\hline Cash Reserve Ratio (CRR) & 1966 \\
\hline Refinance Rate & 1967 \\
\hline Bank Rate & 1967 \\
\hline Statutory Liquidity Ratio (SLR) & 1974 \\
\hline Open Market Operations (Primary) & 1988 \\
\hline Open Market Operations (Secondary) & 1994 \\
\hline Fixation of interest rate & 1966 \\
\hline Fixation of interest rate (Adjusted with Market) & 1971 \\
\hline Partial Deregulation of Interest Rate & 1986 \\
\hline Interest Rate Liberalization & 1989 \\
\hline
\end{tabular}

\section{After 2002}

Source : Authors' compilation from NRB publications

NRB Act, 2002 is landmark for providing legal and institutional framework for monetary policy. It was made mandatory for NRB to formulate annual monetary policy and make it public. Resulting, NRB started formal announcement of monetary policy statement in FY 2002/03 which was a breakthrough in modernizing monetary policy.NRB started mid-term review of monetary policy in 2003/04, quarterly review in 2016/17.

NRB formulates monetary policy as shown in below chart. At first, Research Department (RD) prepares draft collecting information and suggestions from other Departments of the Bank and related stakeholders. The major issues of draft are discussed the Inter-Departmental Coordination Committee, 10-member committee of NRB headed by Executive Director of RD. After discussion, the 
Dhakal, N. K., \& Timsina, M. P. (2020) Price and output effects of Monetary policy in Low Income Countries: The Case of Nepal. Advances in Social Sciences Research Journal, 7(5) 478-495.

policy draft is forwarded to the Management Committee (MC) for further discussion. The draft of monetary policy is again discussed in the Board of Directors (BOD). The BOD finalizes the monetary policy statement and the Governor formally announces the policy and makes it public. The monetary policy formulation process is shown in chart 2.1.

\section{Chart 1: Monetary Policy Formulation Process}

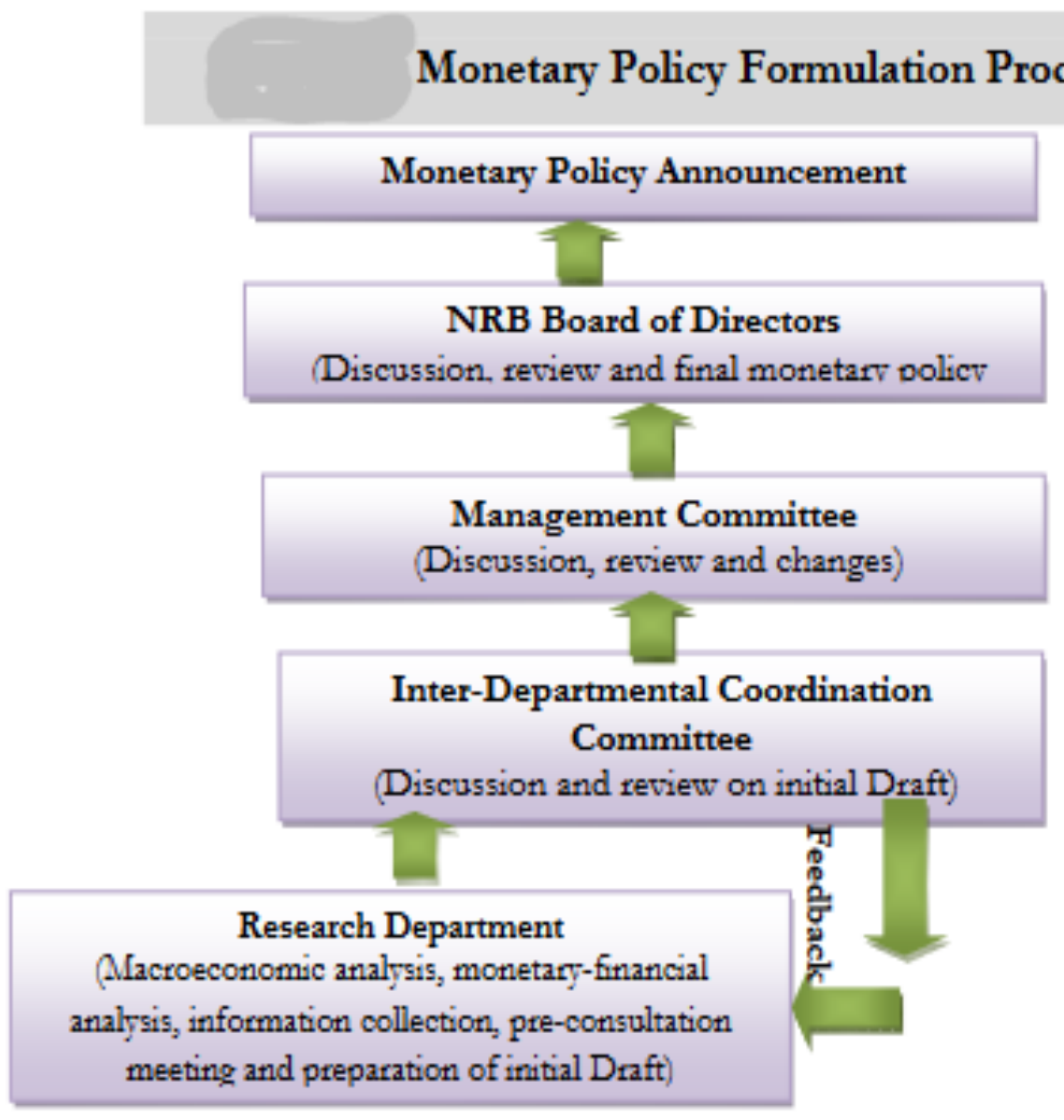

Source: Sixty Years of Nepal Rastra Bank [15]

In the process of formulation of monetary policy, NRB sets inflation goals. Based on the economic growth and inflation, NRB targets the monetary aggregates for the coming fiscal year. Following table shows the targets/goals of economic growth, inflation and monetary aggregates and their actual value. 
Table 2: Targets/Goals and Actual

\begin{tabular}{|r|c|c|c|c|c|c|c|}
\hline \multirow{2}{*}{ Fiscal Year } & \multirow{2}{*}{ Intended Policy Stance } & \multicolumn{2}{|c|}{ Target } & \multicolumn{4}{c|}{ Goals } \\
\cline { 3 - 8 } & & $\mathbf{M 2}^{\mathbf{t}}$ & $\mathbf{M 2}^{\mathbf{a}}$ & $\mathbf{\pi}^{\mathbf{t}}$ & $\mathbf{\pi}^{\mathbf{a}}$ & $\mathbf{Y}^{\mathbf{t}}$ & $\mathbf{Y}^{\mathbf{a}}$ \\
\hline $2002 / 2003$ & accommodative & 12.0 & 9.8 & 4.0 & 4.7 & 4.0 & 3.9 \\
\hline $2003 / 2004$ & accommodative & 11.2 & 12.8 & 4.3 & 4.0 & 4.5 & 4.7 \\
\hline $2004 / 2005$ & tight & 12.5 & 8.3 & 4.0 & 4.5 & 4.5 & 3.5 \\
\hline $2005 / 2006$ & soft & 13.0 & 15.4 & 5.0 & 8.0 & 4.5 & 3.4 \\
\hline $2006 / 2007$ & tight & 16.1 & 14.0 & 6.0 & 5.9 & 5.0 & 3.4 \\
\hline $2007 / 2008$ & soft & 15.6 & 25.2 & 5.5 & 6.7 & 5.0 & 6.1 \\
\hline $2008 / 2009$ & cautious & 18.5 & 27.3 & 7.5 & 12.6 & 7.0 & 4.5 \\
\hline $2009 / 2010$ & cautious and tight & 17.0 & 14.1 & 7.0 & 9.6 & 5.5 & 4.8 \\
\hline $2010 / 2011$ & cautious and tight & 15.0 & 28.0 & 7.0 & 9.6 & 4.5 & 3.4 \\
\hline $2011 / 2012$ & balanced and cautious & 12.5 & 22.7 & 7.0 & 8.3 & 5.0 & 4.8 \\
\hline $2012 / 2013$ & cautious and balanced & 15.0 & 16.4 & 7.5 & 9.9 & 5.3 & 4.1 \\
\hline $2013 / 2014$ & flexible and cautious & 16.0 & 19.1 & 8.0 & 9.1 & 5.5 & 6.0 \\
\hline $2014 / 2015$ & & 16.0 & 19.9 & 8.0 & 7.2 & 6.0 & 3.3 \\
\hline $2015 / 2016$ & cautious and balanced & 18.0 & 19.5 & 8.5 & 9.9 & 6.0 & 0.6 \\
\hline $2016 / 2017$ & cautious and balanced & 17.0 & 15.5 & 7.5 & 4.5 & 6.5 & 8.2 \\
\hline $2017 / 2018$ & cautious and balanced & 18.0 & 19.4 & 7.0 & 4.2 & 7.2 & 6.7 \\
\hline $2018 / 2019$ & cautious and balanced & 18.0 & 15.8 & 6.5 & 4.5 & 8.0 & 7.1 \\
\hline Source: Author': t- targetd growth rate in percent, a- actual growth rate in percent & & \\
\hline
\end{tabular}

\section{Data and Model Specification}

\section{METHODOLOGY}

This study has used inferential statistics to analyze the relationship between selected variables. The study has used quarterly data series from first quarter of 2006 to fourth quarter of 2018 (first month refers mid-January to mid-February and so on). The data are collected from national accounts data of Central Bureau of Statistics (CBS) [18] and Quarterly Economic Bulletin and Current Macroeconomic and Financial Situation published by the Nepal Rastra Bank.

The study uses economic growth, inflation, money supply, interbank rate of commercial banks, cash reserve ratio for commercial bank (CRR) and bank rate. In order to evaluate the impact, the response of economic growth with money supply, CRR, bank rate and such response of inflation with these variables has been examined.

\section{Variables and their definition}

Y=Economic Growth Rate,

$\Pi=$ Inflation Rate

$\mathrm{BR}=$ Bank Rate, 
Dhakal, N. K., \& Timsina, M. P. (2020) Price and output effects of Monetary policy in Low Income Countries: The Case of Nepal. Advances in Social Sciences Research Journal, 7(5) 478-495.

CRR = Cash Reserve Ratio for commercial banks

M1 = Money Supply Growth Rate

M2=Broad Money Growth Rate

PCR = Private Sector Credit Growth Rate

$\mathrm{IR}=$ Interbank rate of commercial banks

Along with these, two dummy variables have been introduced in models.

Dum = blockade in 2015(2015Q3 and Q4)

Dum_Pol_Sit = Period after promulgation of constitution, 2015

\section{Relationship between variables}

\section{Monetary Policy and Economic Growth}

The impact of monetary policy falls on economic activities. Hence, economic growth is function of monetary policy instruments and indicators.

$$
\begin{aligned}
& Y=a_{1}+b_{1} C R R+c_{1} B R+d_{1} M 1+f_{1} I R+e_{1} \ldots \\
& Y=a_{2}+b_{2} C R R+c_{2} B R+d_{2} M 2+f_{2} I R+e_{2} \ldots \\
& Y=a_{3}+b_{3} C R R+c_{3} B R+d_{3} P C R+f_{3} I R+e_{3} .
\end{aligned}
$$

\section{Monetary Policy to Inflation}

The impact of monetary policy falls on general price level. Hence, inflation is function of monetary policy instruments and indicators.

$$
\begin{aligned}
& \Pi=\mathrm{a}_{4}+\mathrm{b}_{4} \mathrm{CRR}+\mathrm{c}_{4} \mathrm{BR}+\mathrm{d}_{4} \mathrm{M} 1+\mathrm{f}_{4} \mathrm{IR}+\mathrm{e}_{4} \ldots \\
& \prod=\mathrm{a}_{5}+\mathrm{b}_{5} \mathrm{CRR}+\mathrm{c}_{5} \mathrm{BR}+\mathrm{d}_{5} \mathrm{M} 2+\mathrm{f}_{5} \mathrm{IR}+\mathrm{e}_{5} \ldots \\
& \prod=\mathrm{a}_{6}+\mathrm{b}_{6} \mathrm{CRR}+\mathrm{c}_{6} \mathrm{BR}+\mathrm{d}_{6} \mathrm{PCR}+\mathrm{f}_{6} \mathrm{IR}+\mathrm{e}_{6}
\end{aligned}
$$

Furthermore, output and inflation are also determined by their past behaviors and past behavior of monetary policy instruments. In such cases, the above mentioned models can be written as

\section{Monetary Policy and Economic Growth}

The impact of monetary policy falls on economic activities. Hence, economic growth is function of monetary policy instruments and indicators.

$$
\begin{aligned}
& \mathrm{Y}=\mathrm{k}_{1}+\mathrm{a}_{1 \mathrm{k}} \mathrm{Y}(-\mathrm{k})+\mathrm{b}_{1 \mathrm{k}} \operatorname{CRR}(-\mathrm{k})+\mathrm{c}_{1 \mathrm{k}} \mathrm{BR}(-\mathrm{k})+\mathrm{d}_{1 \mathrm{k}} \mathrm{M} 1(-\mathrm{k})+\mathrm{f}_{1 \mathrm{k}} \operatorname{IR}(-\mathrm{k})+\mathrm{e}_{7} \ldots \ldots \ldots \ldots . . .(7) \\
& \mathrm{Y}=\mathrm{k}_{2}+\mathrm{a}_{21} \mathrm{Y}(-\mathrm{l})+\mathrm{b}_{21} \operatorname{CRR}(-1)+\mathrm{c}_{21} \mathrm{BR}(-1)+\mathrm{d}_{21} \mathrm{M} 2(-1)+\mathrm{f}_{21} \operatorname{IR}(-\mathrm{l})+\mathrm{e}_{8} \ldots \ldots \ldots \ldots . .(8) \\
& \mathrm{Y}=\mathrm{k}_{3}+\mathrm{a}_{3 \mathrm{~m}} \mathrm{Y}(-\mathrm{m})+\mathrm{b}_{3 \mathrm{~m}} \mathrm{CRR}(-\mathrm{m})+\mathrm{c}_{3 \mathrm{~m}} \mathrm{BR}(-\mathrm{m})+\mathrm{d}_{3 \mathrm{~m}} \operatorname{PCR}(-\mathrm{m})+\mathrm{f}_{3 \mathrm{~m}} \operatorname{IR}(-\mathrm{m})+\mathrm{e}_{9} \ldots . .(9) \\
& \mathrm{k} \text { to } \mathrm{m} \text { range from } 0,1,2, . . \mathrm{n}
\end{aligned}
$$

\section{Monetary Policy to Inflation}

The impact of monetary policy falls on general price level. Hence, inflation is function of monetary policy instruments and indicators.

$$
\begin{aligned}
& \Pi=\mathrm{k}_{4}+\mathrm{a}_{4 \mathrm{r}} \mathrm{Y}(-\mathrm{r})+\mathrm{b}_{4 \mathrm{r}} \mathrm{CRR}(-\mathrm{r})+\mathrm{c}_{4 \mathrm{r}} \mathrm{BR}(-\mathrm{r})+\mathrm{d}_{4 \mathrm{r}} \mathrm{M} 1(-\mathrm{r})+\mathrm{f}_{4 \mathrm{r}} \operatorname{IR}(-\mathrm{r})+\mathrm{e}_{10} \ldots \\
& \Pi=\mathrm{k}_{5}+\mathrm{a}_{5 \mathrm{~s}} \mathrm{Y}(-\mathrm{s})+\mathrm{b}_{5 \mathrm{~s}} \mathrm{CRR}(-\mathrm{s})+\mathrm{c}_{5 \mathrm{~s}} \mathrm{BR}(-\mathrm{s})+\mathrm{d}_{5 \mathrm{~s}} \mathrm{M} 2(-\mathrm{s})+\mathrm{f}_{5 \mathrm{~s}} \operatorname{IR}(-\mathrm{s})+\mathrm{e}_{10} .
\end{aligned}
$$


$\Pi=\mathrm{k}_{6}+\mathrm{a}_{6 \mathrm{t}} \mathrm{Y}(-\mathrm{p})+\mathrm{b}_{6 \mathrm{t}} \mathrm{CRR}(-\mathrm{p})+\mathrm{c}_{6 \mathrm{t}} \mathrm{BR}(-\mathrm{p})+\mathrm{d}_{6 \mathrm{t}} \operatorname{PCR}(-\mathrm{p})+\mathrm{f}_{6 \mathrm{t}} \operatorname{IR}(-\mathrm{p})+\mathrm{e}_{11} \ldots .(12)$

$r$ to $t$ range from $1,2, . . n$

Hence, there is scope of 6 bivariate models in analysis.

Methods of analysis

Time series econometrics has been used to estimate and analyse the coefficients. This work uses the methods of analysis as below.

\section{Unit Root Test}

ARMA is estimated based on stationary time series. A series is called (weakly or covariance) stationary if it's mean and auto covariance do not depend on time. The series that is not stationary is called non-stationary. The random walk is an example of a non-stationary series:

$$
y_{t}=y_{t-1}+e_{1}
$$

Where, e is a stationary random disturbance term and y has a constant forecast value, conditional on $t$, and the variance is increasing over time. The random walk is a difference stationary series since the first difference of $y$ is stationary:

$$
y_{t}-y_{t-1}=(1-L) y_{t}=e_{1}
$$

A difference stationary series is called integrated and noted as I(d) where d refers order of integration. The order of integration is the number of unit roots contained in the series, or the number of differencing operations it takes to make the series stationary. For the random walk above, there is one unit root, so it is an I(1) series. Standard inference procedures do not apply to regressions which contain an integrated dependent variable or integrated repressor. Hence, it is important to check whether a series is stationary exist before using it in a regression. The formal method to test the stationary of a series is the unit root test [19].

\section{Auto Regressive Distributed Lag (ARDL)}

The ARDL co-integration procedure has been used to examine the long-run relationship between the dependent and independent variables. One important feature of the test is that it is free from unit-root pre-testing. It can be applied whether variables are I(0) or I(1). The short run and long run parameters can be drawn by applying ARDL with an appropriate lag length.

\section{Bound Test}

This study applies Bound Test to examine the existence of the long run equilibrium relationship among variables because of the presence of stationary and non-stationary data. Bounds at 1 percent, 5 percent and 10 percent level of significance are compared with the value of F-Statistic.

Table 3: Bound Test

\begin{tabular}{|c|c|}
\hline Cases & Conclusion \\
\hline If F-Statistics greater than I(1) & There exist co-integration \\
\hline If F-Statistics less than I(0) & There does not exist co-integration \\
\hline If F-Statistics lies in-between I(0) and I(1) & Inconclusive \\
\hline
\end{tabular}


Dhakal, N. K., \& Timsina, M. P. (2020) Price and output effects of Monetary policy in Low Income Countries: The Case of Nepal. Advances in Social Sciences Research Journal, 7(5) 478-495.

\section{Error Correction Model}

This study examines the speed at which dependent variable returns to equilibrium as a result of a change in dependent variables. It is an adjustment of short term towards the long term equilibrium using error correction model. The error correction model based on the relationship between monetary policy to economic growth and inflation are tested in the study. If the coefficient of the coint(-1) is negative, there exist correction of disequilibrium. Furthermore, higher value of coefficient indicates faster correction of disequilibrium in the model.

\section{Residual Test}

The residual tests have been applied to know the normality of distribution of residual, absence of serial correlation and constant variance. The serial correlation has been tested by using BreuschGodfrey Serial Correlation LM tests; heteroscedasticity is checked by using Breusch-Pagan Godfrey test; and normality using Jarque-Bera test at 5 percent level of significance.

Table 4: Residual Test

\begin{tabular}{|c|c|c|c|}
\hline Residual & Test & Null Hypothesis & Expected Value \\
\hline Serial Correlation & $\begin{array}{c}\text { Breusch-Godfrey } \\
\text { LM test }\end{array}$ & No serial correlation & $\begin{array}{c}\text { P-value of test statistics } \\
\text { greater than 5 percent. }\end{array}$ \\
\hline Heteroscedasticity & $\begin{array}{c}\text { Breusch-Pagan } \\
\text { Godfrey test }\end{array}$ & Homoscedasticity & $\begin{array}{c}\text { P-value of test statistics } \\
\text { greater than 5 percent. }\end{array}$ \\
\hline Normality & Jarque-Bera & Normally distributed & $\begin{array}{c}\text { P-value of test statistics } \\
\text { greater than 5 percent. }\end{array}$ \\
\hline
\end{tabular}

\section{Stability Test}

This study applies CUSUM test to examine the stability of the parameters in all equations at 5 percent level of significance. Cusum and cusum of square tests have been applied in each equation. The parameter stability exists if the cumulative sum remained within the area between the two critical lines. It means the movement outside the critical lines is instability in parameter.

\section{Results of Unit Root Test}

\section{EMPIRICAL ANALYSIS}

As mentioned in methodology, stationarity of all series is checked using the Augmented DickeyFuller unit root tests. Furthermore, Akike Criterion has been applied. They have been found stationary at level I(0) and first difference I(1). The result of the Augmented Dickey-Fuller unit root tests are presented in Table 1.

Table 5: Unit Root Test

\begin{tabular}{|c|c|c|c|c|c|c|}
\hline \multirow[b]{2}{*}{ Description } & \multicolumn{3}{|c|}{ Level } & \multicolumn{3}{|c|}{ 1st Difference } \\
\hline & Intercept & $\begin{array}{c}\text { Trend \& } \\
\text { Intercept }\end{array}$ & None & Intercept & $\begin{array}{c}\text { Trend \& } \\
\text { Intercept }\end{array}$ & None \\
\hline $\mathrm{Y}$ & $-3.38^{* *}$ & $-3.44^{* * *}$ & -0.02 & $-4.85^{*}$ & $-4.87^{*}$ & $-4.9 *$ \\
\hline$\Pi$ & -2.43 & -2.74 & -0.98 & $-6.16^{*}$ & $-5.4^{*}$ & $-6.21^{*}$ \\
\hline CRR & -1.76 & -1.21 & -0.23 & $-4.9 *$ & $-5^{*}$ & $-4.99 *$ \\
\hline BR & -1.65 & -0.88 & 0.16 & $-7.08 *$ & $-7.37 *$ & $-7.14^{*}$ \\
\hline IR & $-2.89 * *$ & $-3.17^{* * *}$ & $-1.86^{* * *}$ & $-6.42 *$ & $-6.34^{*}$ & $-6.49 *$ \\
\hline M1 & $-2.6^{* * *}$ & -2.53 & -0.71 & $-5.6^{*}$ & $-5.56^{*}$ & $-5.66^{*}$ \\
\hline M2 & -2.12 & -2.95 & $-1.81^{* * *}$ & $-5.08^{*}$ & $-5.01^{*}$ & $-4.92 *$ \\
\hline PCR & $-3.13^{* *}$ & -2.81 & -0.60 & -1.90 & -1.88 & $-1.93^{* *}$ \\
\hline
\end{tabular}


The test result shows that economic growth rate, interbank rate and growth rate of M1 and private sector credit are I(0) whereas other variables are I(1). Hence, there is scope of autoregressive distributed lag models (ARDLs). Following section covers the empirical relation among the variables.

\section{Impact of monetary Policy}

The impact of monetary policy is broadly observed here in two categories a) output, and b) inflation. The impact has been observed in five models in each category using common independent variables such as cash reserve ratio, bank rate, interbank rate and separate independent variables such as money supply, broad money and credit to private sector.

\section{Output}

The impact on output has been observed in three models.

\section{Equation Estimation}

\section{Money Supply (M1)}

$\mathrm{Y}=0.25 * \mathrm{Y}(-1)-0.01 * \mathrm{Y}(-2)-0.13 * \mathrm{Y}(-3)-0.29 * \mathrm{Y}(-4)+0.03 * \mathrm{M} 1+0.06 * \mathrm{IR}-0.05 * \mathrm{IR}(-1)-$ $[2.02]^{* * *} \quad[-0.05] \quad[-0.96] \quad[-2.38]^{* *} \quad[0.64] \quad[0.35] \quad[-0.24]$

$0.43 * \operatorname{IR}(-2)+0.23 * \operatorname{IR}(-3)-0.83 * \mathrm{CRR}+1.64 * \mathrm{CRR}(-1)+0.17 * \mathrm{CRR}(-2)-5.91 * \mathrm{CRR}(-3)+6.30 * \mathrm{CRR}(-4)$
$[-2.15]^{* *} \quad[1.30]$
$[-0.84]$
[1.30]
[0.09]
$[-2.75]^{*}$
$[4.28]^{*}$

$-0.55^{*} \mathrm{BR}-8.33^{*} \mathrm{DUM}+1.96$

$[-0.85] \quad[-4.15]^{*} \quad[0.32]$

R-squared: 0.81

F-Statistic: 9.04

Adjusted R-Squared: 0.72

Prob(F-Statistic) : 0.00

DW : 1.92

R-squared shows 0.81 and Adjusted R-squared shows 0.72 . These indicate economic growth is well explained by past behaviour of economic growth and monetary policy indicators.

The output shows that economic growth of one quarter lag and a year ago, two quarter lag interbank rate, third quarter lag and a year ago CRR affect the GDP growth. Money supply is not significant to economic growth.

\section{Broad Money (M2)}

$\mathrm{Y}=0.28 * \mathrm{Y}(-1)-0.02 * \mathrm{Y}(-2)-0.11 * \mathrm{Y}(-3)-0.46 * \mathrm{Y}(-4)-0.06 * \mathrm{M} 2-0.01 * \mathrm{M} 2(-1)+0.004 * \mathrm{M} 2(-2)+$

$[2.18]^{* *} \quad[-0.17] \quad[-0.82] \quad[-3.71]^{*} \quad[-0.71] \quad[-0.091] \quad[0.04]$

$0.20 * \mathrm{M} 2(-3)+0.30 * \mathrm{IR}-0.37 * \mathrm{IR}(-1)-2.85 * \mathrm{CRR}+1.08 * \mathrm{BR}+2.21 * \mathrm{DUM}$-POL +10.76

$[2.23]^{* *} \quad[1.32] \quad[-1.73]^{* * *} \quad[-2.95]^{*} \quad[1.11] \quad[2.06]^{* *} \quad[1.49]$

R-squared: 0.68

F-Statistic: 5.61

Adjusted R-Squared: 0.56

Prob(F-Statistic) : 0.00

DW : 1.62

R-squared shows 0.68 and Adjusted R-squared shows 0.56 . These indicate economic growth is well explained by past behaviour of economic growth and monetary policy indicators. 
Dhakal, N. K., \& Timsina, M. P. (2020) Price and output effects of Monetary policy in Low Income Countries: The Case of Nepal. Advances in Social Sciences Research Journal, 7(5) 478-495.

The output shows that economic growth of one quarter lag and a year ago, third quarter lag of broad money, one quarter lag interbank rate, CRR, and political stability affect the GDP growth. Result shows that 0.20 percentage point increase in economic growth as a result of one percentage point increase in broad money of three quarter ago.

\section{Private Sector Credit (PCR)}

$$
\begin{aligned}
& \mathrm{Y}=0.26 * \mathrm{Y}(-1)+0.03 * \mathrm{Y}(-2)-0.15 * \mathrm{Y}(-3)-0.40 * \mathrm{Y}(-4)-0.09 * \mathrm{PCR}-0.01 * \mathrm{PCR}(-1)-0.02 * \mathrm{PCR}(-2) \\
& {[2.41]^{* *} \quad[0.28] \quad[-1.22] \quad[-3.58]^{*} \quad[-2.00]^{* * *}[-0.19] \quad[-0.52]} \\
& +0.15 * \text { PCR }(-3)+0.14 * \operatorname{IR}-0.20 * \operatorname{IR}(-1)-0.38 * \operatorname{IR}(-2)-1.49 * \mathrm{CRR}+1.43 * \mathrm{CRR}(-1)+0.53 * \mathrm{CRR}(-2) \\
& \left.\begin{array}{llllll}
{[3.67]^{*}} & {[0.88]} & {[-1.10]} & {[2.44]^{* *}} & {[-1.66]} & {[1.27]}
\end{array}\right] \\
& -5.65 * \mathrm{CRR}(-3)+5.48 * \mathrm{CRR}(-4)-0.50 * \mathrm{BR}-7.85 * \mathrm{DUM}+8.34 \\
& {[-3.00]^{*} \quad[4.07]^{*} \quad[-0.74] \quad[-4.40]^{*}[1.22]}
\end{aligned}
$$

R-squared: 0.86

Adjusted R-Squared: 0.78
F-Statistic: 10.9

Prob(F-Statistic) : 0.00

DW : 2.02

R-squared shows 0.86 and Adjusted R-squared shows 0.78 . These indicate economic growth is well explained by past behaviour of economic growth and monetary policy indicators.

The output shows that economic growth of one quarter lag and a year ago, third quarter lag of

\begin{tabular}{|c|c|c|c|c|}
\hline Test Statistic & Value & Signif. & $I(0)$ & $I(1)$ \\
\hline \multicolumn{5}{|c|}{ Narrow Money } \\
\hline F-statistic & 12.73 & $10 \%$ & 2.614 & 3.746 \\
\hline \multirow[t]{2}{*}{$\mathrm{K}$} & 4 & $5 \%$ & 3.136 & 4.416 \\
\hline & & $1 \%$ & 4.306 & 5.874 \\
\hline \multicolumn{5}{|c|}{ Broad Money } \\
\hline F-statistic & 20.2 & $10 \%$ & 3.333 & 4.313 \\
\hline \multirow[t]{2}{*}{$\mathrm{K}$} & 2 & $5 \%$ & 4.07 & 5.19 \\
\hline & & $1 \%$ & 5.817 & 7.303 \\
\hline \multicolumn{5}{|c|}{ Private Sector Credit } \\
\hline F-statistic & 16.5 & $10 \%$ & 2.614 & 3.746 \\
\hline \multirow[t]{2}{*}{$\mathrm{K}$} & 4 & $5 \%$ & 3.136 & 4.416 \\
\hline & & $1 \%$ & 4.306 & 5.874 \\
\hline
\end{tabular}
private sector credit, two quarter lag interbank rate, three quarter lag of CRR affect the GDP growth. Result shows that 0.15 percentage point increase in economic growth as a result of one percentage point increase in private sector credit of three quarter ago.

\section{Bound Test}

Table 6: Bound Test

At the 5 percent level of significance, the value of $F$ statistics is greater than the value at I(1). It means there exists co-integration in each models. There exists long-run relationship between variables. 


\section{Error Correction Model}

\begin{tabular}{|c|c|c|c|c|c|c|c|}
\hline Variable & Coefficient & t-Statistic & Prob. & Variable & Coefficient & t-Statistic & Prob. \\
\hline $\mathrm{C}$ & \begin{tabular}{|l|}
1.96 \\
\end{tabular} & 5.52 & 0.00 & $\mathrm{C}$ & 10.76 & 2.06 & 0.05 \\
\hline $\mathrm{D}(\mathrm{Y}(-1))$ & 0.42 & 4.05 & 0.00 & $\mathrm{D}(\mathrm{Y}(-1))$ & 0.60 & 4.56 & 0.00 \\
\hline $\mathrm{D}(\mathrm{Y}(-2))$ & 0.42 & 3.82 & 0.00 & $\mathrm{D}(\mathrm{Y}(-2))$ & 0.57 & 4.66 & 0.00 \\
\hline$\frac{\mathrm{D}(\mathrm{Y}(-3))}{\mathrm{D}(\mathrm{IR})}$ & $\begin{array}{l}0.29 \\
0.06\end{array}$ & $\begin{array}{l}2.69 \\
0.41\end{array}$ & $\begin{array}{l}0.01 \\
0.68\end{array}$ & $\mathrm{D}(\mathrm{Y}(-3))$ & 0.46 & 3.89 & 0.00 \\
\hline $\mathrm{D}(\operatorname{IR}(-1))$ & 0.20 & 1.28 & 0.21 & $\mathrm{D}(\mathrm{M} 2)$ & -0.06 & -0.80 & 0.43 \\
\hline $\mathrm{D}(\operatorname{IR}(-2))$ & -0.23 & -1.52 & 0.14 & $\mathrm{D}(\mathrm{M} 2(-1))$ & -0.20 & -2.29 & 0.03 \\
\hline $\mathrm{D}(\mathrm{CRR})$ & -0.83 & -1.01 & 0.32 & $\mathrm{D}(\mathrm{M} 2(-2))$ & -0.20 & -2.46 & 0.02 \\
\hline $\mathrm{D}(\mathrm{CRR}(-1))$ & -0.56 & -0.66 & 0.51 & $\mathrm{D}(\mathrm{IR})$ & 0.30 & 1.58 & 0.12 \\
\hline $\mathrm{D}(\mathrm{CRR}(-2))$ & $\frac{-0.39}{620}$ & -0.28 & 0.78 & CRR & -2.85 & -3.19 & 0.00 \\
\hline$\frac{\mathrm{D}(\mathrm{CRR}(-3))}{\text { DUM }}$ & $\begin{array}{l}-6.30 \\
-8.33\end{array}$ & $\begin{array}{l}-4.96 \\
-4.60\end{array}$ & $\begin{array}{l}0.00 \\
0.00\end{array}$ & B_RATE & 1.08 & 1.56 & 0.13 \\
\hline CointEq(-1)* & -1.17 & -8.45 & 0.00 & DUM_POL_SIT & 2.21 & 2.42 & 0.02 \\
\hline R-squared & 0.81 & & & CointEq(-1)* & -1.31 & -7.97 & 0.00 \\
\hline $\begin{array}{l}\text { Adjusted R- } \\
\text { sauared }\end{array}$ & 0.75 & & & \begin{tabular}{|c|} 
R-squared \\
\end{tabular} & 0.68 & DW: & \\
\hline squared & 13.24 & & & Adjusted R-squared & 0.58 & & \\
\hline Prob(F-statistic) & 0.00 & DW & 1.92 & \begin{tabular}{|l|} 
F-statistic \\
\end{tabular} & 7.04 & & \\
\hline & & & & Prob(F-statistic) & 0.00 & & \\
\hline Variable & Coefficient & t-Statistic & Prob. & & & & \\
\hline $\mathrm{C}$ & \begin{tabular}{|l|}
8.34 \\
\end{tabular} & \begin{tabular}{|l|}
9.59 \\
\end{tabular} & 0.00 & & & & \\
\hline $\mathrm{D}(\mathrm{Y}(-1))$ & 0.52 & 5.22 & 0.00 & & & & \\
\hline $\mathrm{D}(\mathrm{Y}(-2))$ & 0.55 & 5.32 & 0.00 & & & & \\
\hline $\mathrm{D}(\mathrm{Y}(-3))$ & 0.40 & 3.88 & 0.00 & & & & \\
\hline D(PCR) & -0.09 & -2.47 & 0.02 & & & & \\
\hline $\mathrm{D}(\mathrm{PCR}(-1))$ & -0.13 & -3.56 & 0.00 & & & & \\
\hline $\mathrm{D}(\mathrm{PCR}(-2))$ & -0.15 & -4.35 & 0.00 & & & & \\
\hline $\mathrm{D}(\mathrm{IR})$ & 0.14 & 1.02 & 0.32 & & & & \\
\hline $\mathrm{D}(\operatorname{IR}(-1))$ & 0.38 & 2.85 & 0.01 & & & & \\
\hline $\mathrm{D}(\mathrm{CRR})$ & -1.49 & -2.09 & 0.05 & & & & \\
\hline D(CRR(-1)) & -0.36 & -0.49 & 0.63 & & & & \\
\hline D(CRR(-2)) & 0.17 & 0.14 & 0.89 & & & & \\
\hline $\mathrm{D}(\mathrm{CRR}(-3))$ & -5.48 & -4.77 & 0.00 & & & & \\
\hline DUM & -7.85 & -5.00 & 0.00 & & & & \\
\hline CointEq(-1)* & -1.25 & -9.66 & 0.00 & & & & \\
\hline R-squared & 0.86 & \multicolumn{2}{|c|}{ DW : 2.01} & & & & \\
\hline $\begin{array}{c}\text { Adjusted R- } \\
\text { squared }\end{array}$ & 0.81 & & & & & & \\
\hline F-statistic & 15.57 & & & & & & \\
\hline Prob(F-statistic) & 0.00 & & & & & & \\
\hline
\end{tabular}

In each case, co-integration is significant and it follows an expected sign (-). The result shows that the correction is faster at more than 100 percent. Corrections of disequilibrium are faster in models those included M2 and Private Sector Credit. 
Dhakal, N. K., \& Timsina, M. P. (2020) Price and output effects of Monetary policy in Low Income Countries: The Case of Nepal. Advances in Social Sciences Research Journal, 7(5) 478-495.

\section{Residual Test}

Table 7: Residual Tests

\begin{tabular}{|c|c|c|c|}
\hline & $\begin{array}{c}\text { Normality } \\
\text { Test }\end{array}$ & $\begin{array}{c}\text { Serial Correlation } \\
\text { Test }\end{array}$ & Heteroscedastity Test \\
\hline M1 & $0.69(0.71)$ & $5.51(0.06)$ & $8.99(0.91)$ \\
\hline M2 & $0.05(0.97)$ & $3.74(0.15)$ & $13.6(0.41)$ \\
\hline Private Sector Credit & $1.47(0.48)$ & $5.54(0.06)$ & $13.8(0.74)$ \\
\hline
\end{tabular}

*values in parenthesis show the p-value

The null hypotheses of residual tests state that errors are normally distributed with no serial correlation and homoscedasticity. The value of parenthesis are greater than 0.05 . This indicates that null hypothesis cannot be rejected. Hence, conclusion can be drawn as errors are normally distributed, no serial correlation and constant variance at 5 percent level of significance.

\section{Stability Test}

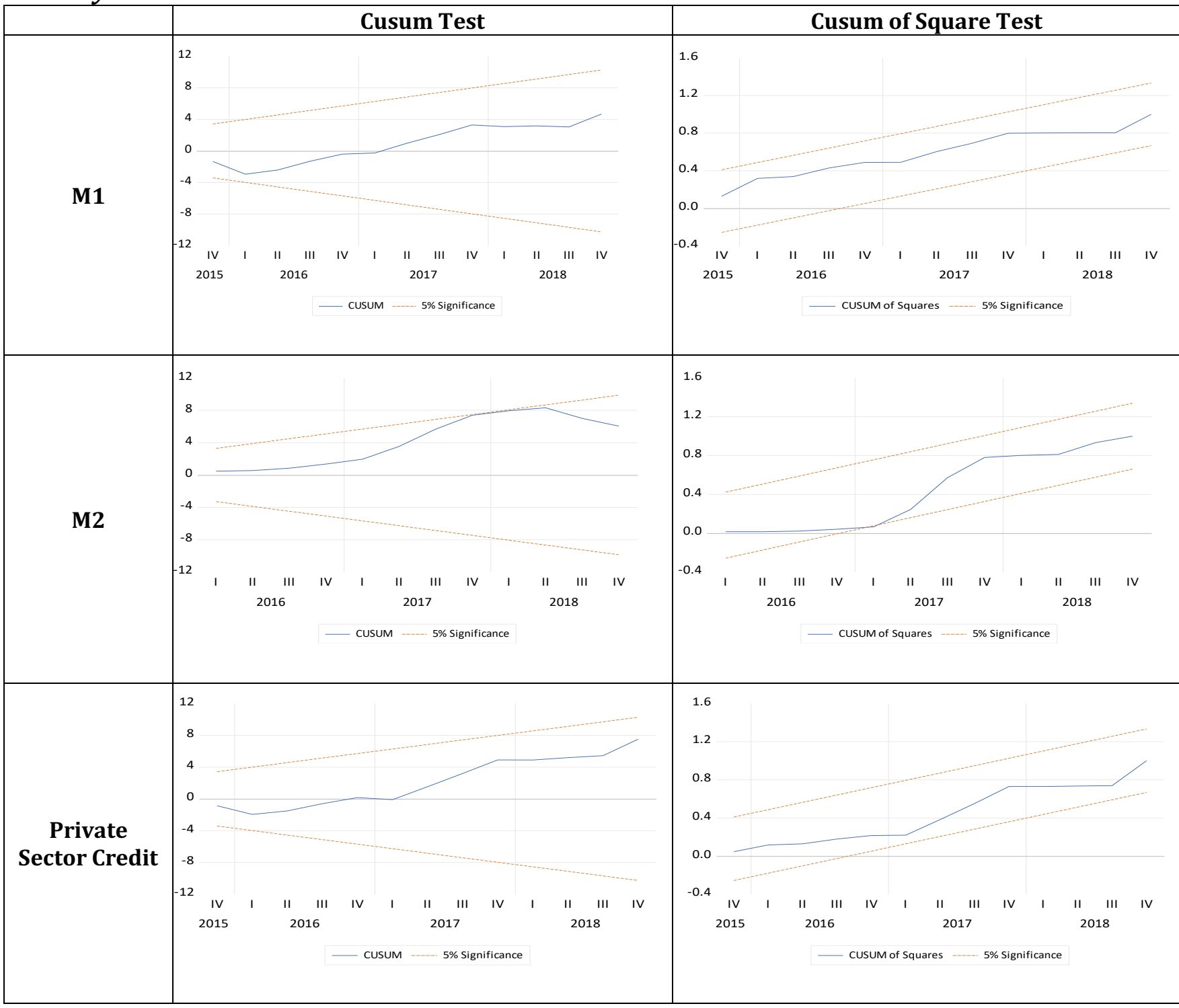

Cusum and cusum of square tests show the stability of estimated models. 


\section{Inflation}

The impact on inflation has also been observed in three models.

\section{Equation Estimation}

Money Supply (M1)

$$
\begin{aligned}
& \Pi=1.09 * \Pi(-1)-0.44 * \Pi(-2)-0.07 * \mathrm{M} 1+0.20 * \mathrm{M} 1(-1)-0.15^{*} \mathrm{M} 1(-2)+0.17 * \mathrm{IR}-0.15^{*} \mathrm{IR}(-1)+ \\
& {[6.75]^{*} \quad[-2.89]^{*} \quad[-1.29] \quad[3.42]^{*} \quad[-3.71]^{*} \quad[1.64] \quad[-1.21]} \\
& 0.17 * \mathrm{CRR}+0.69 * \mathrm{CRR}(-1)+1.24 * \mathrm{CRR}(-2)-1.53 * \mathrm{CRR}(-3)+1.76^{*} \mathrm{CRR}(-4)+1.63 * \mathrm{BR}-4.10 * \mathrm{BR}(-1) \\
& {[0.26] \quad[0.81] \quad[1.23] \quad[-1.52] \quad[1.96]^{* * *} \quad[1.68] \quad[-2.82]^{*}} \\
& +2.19 * \text { BR(-2) - 2.77*DUM_POL_SIT - } 7.03 \\
& {[2.18]^{* *} \quad[-2.55]^{* *}}
\end{aligned}
$$

R-squared: 0.86

Adjusted R-Squared: 0.79
F-Statistic: 12.35

Prob(F-Statistic) : 0.00

DW : 1.78

R-squared shows 0R-squared shows 0.86 and Adjusted R-squared shows 0.79. These indicate inflation is well explained by past behaviour of inflation and monetary policy variables.

The output shows that inflation rate of first and second quarter lag, money supply at first and second lag, CRR of a year ago affect the inflation rate. One percentage point increase in money supply at first lag leads 0.20 percentage point increase in inflation and one percentage point increase in money supply at second lag leads 0.15 percentage point decrease in inflation.

\section{Broad Money (M2)}

$\Pi=0.87 * \Pi(-1)-0.21 * \Pi(-2)+0.11 * \mathrm{M} 2+0.21 * \mathrm{IR}-0.76^{*} \mathrm{CRR}+1.03 * \mathrm{BR}+2.46 * \mathrm{DUM}-3.29$

$[6.56]^{*} \quad[-1.69]^{* * *} \quad[3.39]^{*} \quad[2.60]^{*}[-1.85]^{* * *}[2.53]^{* *}[2.50]^{* *} \quad[-1.16]$

R-squared: 0.80

Adjusted R-Squared: 0.77
F-Statistic: 25.31

Prob(F-Statistic) : 0.00

DW : 2.03

R-squared shows 0.80 and Adjusted R-squared shows 0.77 . These indicate inflation is well by past behaviour of inflation and monetary policy variables.

The output shows that inflation rate of first and second quarter lag, money supply, CRR and bank rate affect the inflation rate. One percentage point increase in money supply leads 0.11 percentage point increase in inflation at the same quarter.

\section{Private Sector Credit (PCR)}

$$
\begin{aligned}
& \Pi=0.75 * \Pi(-1)+0.11 * \Pi(-2)-0.25 * \Pi(-3)+0.05 * P C R+0.03 * P C R(-1)+0.12 * I R+0.008 * \operatorname{IR}(-1) \\
& {[5.14]^{*} \quad[0.59] \quad[-1.91]^{* * *}[2.24]^{* *} \quad[1.21] \quad[1.12] \quad[0.07]} \\
& -0.13 * \operatorname{IR}(-2)+0.08 * \operatorname{IR}(-3)+0.24 * \operatorname{IR}(-4)-0.75^{*} \mathrm{CRR}+4.14 * \mathrm{BR}-2.92 * \mathrm{BR}(-1)+5.14 * \mathrm{DUM}-4.33 \\
& {[-1.20]}
\end{aligned}
$$

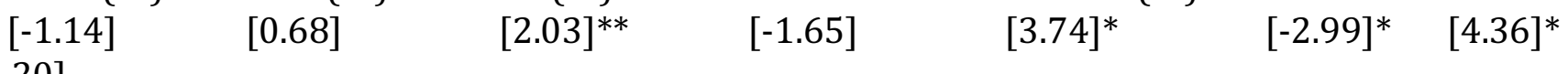


Dhakal, N. K., \& Timsina, M. P. (2020) Price and output effects of Monetary policy in Low Income Countries: The Case of Nepal. Advances in Social Sciences Research Journal, 7(5) 478-495.

R-squared: 0.84

F-Statistic: 13.91

Adjusted R-Squared: 0.78

Prob(F-Statistic) : 0.00

DW : 2.24

R-squared shows 0.84 and Adjusted R-squared shows 0.78. These indicate inflation is well explained by past behaviour of inflation and monetary policy variables.

The output shows that inflation rate of first and third quarter lag, private sector credit, interbank rate of a year ago and bank rate affect the inflation rate. One percentage point increase in private sector credit leads 0.05 percentage point increase in inflation at the same quarter.

\section{Bound Test}

The following tests show that there exists co-integration.

Table 10: Bound Test

\begin{tabular}{|c|c|c|c|c|}
\hline Test Statistic & Value & Signif. & I(0) & I(1) \\
\hline \multicolumn{5}{|c|}{ Narrow Money } \\
\hline F-statistic & 3.90 & $10 \%$ & 2.614 & 3.746 \\
\hline $\mathrm{k}$ & 4 & $5 \%$ & 3.136 & 4.416 \\
\hline \multicolumn{5}{|c|}{ Broad Money } \\
\hline F-statistic & 7.12 & $10 \%$ & 4.306 & 5.874 \\
\hline $\mathrm{k}$ & 2 & $5 \%$ & 3.28 & 4.273 \\
\hline \multicolumn{5}{|c|}{ Private Sector Credit } \\
\hline F-statistic & 5.02 & $10 \%$ & 5.707 & 6.09 \\
\hline $\mathrm{k}$ & 4 & $5 \%$ & 2.578 & 3.068 \\
\hline \multicolumn{7}{|c|}{} & $1 \%$ & 4.244 & 4.334 \\
\hline & & $1 \%$ & 5.726 \\
\hline
\end{tabular}




\section{Error Correction Model}

\begin{tabular}{|c|c|c|c|c|c|c|c|}
\hline \multirow{2}{*}{$\begin{array}{c}\text { Variable } \\
\mathrm{C}\end{array}$} & \multicolumn{2}{|c|}{ Coefficient t-Statistic } & \multirow{2}{*}{$\begin{array}{c}\text { Prob. } \\
0.00 \\
\end{array}$} & \multirow[b]{2}{*}{ Variable } & \multirow[b]{2}{*}{ Coefficient } & \multirow[b]{2}{*}{ t-Statistic } & \multirow[b]{2}{*}{ Prob. } \\
\hline & \begin{tabular}{|l|}
-7.03 \\
\end{tabular} & \begin{tabular}{l|l|} 
& -4.58 \\
\end{tabular} & & & & & \\
\hline $\mathrm{D}(\Pi(-1))$ & 0.44 & 3.23 & 0.00 & $\mathrm{C}$ & -4.33 & -5.41 & 0.00 \\
\hline $\mathrm{D}(\mathrm{M} 1)$ & -0.07 & -1.82 & 0.08 & $\mathrm{D}(\Pi(-1))$ & 0.14 & 1.18 & 0.24 \\
\hline $\mathrm{D}(\mathrm{M} 1(-1))$ & 0.15 & 4.34 & 0.00 & $\mathrm{D}(\mathrm{INF}(-2))$ & 0.25 & 2.11 & 0.04 \\
\hline D(IR) & 0.17 & 1.97 & 0.06 & $\mathrm{D}(\mathrm{PCR})$ & 0.05 & 2.85 & 0.01 \\
\hline D(CRR) & 0.17 & 0.29 & 0.77 & $\mathrm{D}(\mathrm{IR})$ & 0.12 & 1.36 & 0.18 \\
\hline D(CRR(-1)) & -1.47 & -2.48 & 0.02 & $\mathrm{D}(\operatorname{IR}(-1))$ & -0.19 & -2.01 & 0.05 \\
\hline D(CRR(-2)) & -0.24 & -0.34 & 0.74 & $\mathrm{D}(\operatorname{IR}(-2))$ & -0.32 & -3.43 & 0.00 \\
\hline $\mathrm{D}(\mathrm{CRR}(-3))$ & -1.76 & -2.60 & 0.01 & $\mathrm{D}(\operatorname{IR}(-3))$ & -0.24 & -2.38 & 0.02 \\
\hline $\mathrm{D}(\mathrm{BR})$ & 1.63 & 1.85 & 0.07 & $\mathrm{D}(\mathrm{BR})$ & 4.14 & 4.15 & 0.00 \\
\hline $\mathrm{D}(\mathrm{BR}(-1))$ & -2.19 & -2.37 & 0.02 & DUM & 5.14 & 4.84 & 0.00 \\
\hline DUM_POL_SIT & -2.77 & -4.47 & 0.00 & CointEq(-1)* & -0.39 & -5.28 & 0.00 \\
\hline CointEq(-1)* & -0.35 & -4.68 & 0.00 & R-squared & 0.531 & DW : 2 . & \\
\hline \begin{tabular}{|l|} 
R-squared \\
\end{tabular} & 0.56 & DW & 1.78 & Adjusted R- & & & \\
\hline Adjusted R-square & 0.42 & & & squared & 0.41 & & \\
\hline F-statistic & 3.99 & & & F-statistic & 4.58 & & \\
\hline Prob(F-statistic) & 0.00 & & & Prob(F-statistic) & 0.00 & & \\
\hline Variable & Coefficient & t-Statistic & Prob. & & & & \\
\hline $\mathrm{C}$ & -3.29 & \begin{tabular}{|l|}
-1.26 \\
\end{tabular} & 0.21 & & & & \\
\hline $\mathrm{D}(\Pi(-1))$ & 0.21 & 1.84 & 0.07 & & & & \\
\hline CRR & -0.76 & -1.96 & 0.06 & & & & \\
\hline BR & 1.03 & 2.75 & 0.01 & & & & \\
\hline DUM & 2.46 & 2.65 & 0.01 & & & & \\
\hline CointEq(-1)* & -0.35 & -4.73 & 0.00 & & & & \\
\hline R-squared & 0.41 & DW & 2.03 & & & & \\
\hline Adjusted R- & 0.35 & & & & & & \\
\hline F-statistic & 6.43 & & & & & & \\
\hline Prob(F-statistic) & 0.00 & & & & & & \\
\hline
\end{tabular}

In each case, co-integration is significant and it follows an expected sign (-). The result shows that disequilibrium is corrected.

\section{Residual Test}

Table 11: Residual Tests

\begin{tabular}{|c|c|c|c|}
\hline & Normality Test & $\begin{array}{c}\text { Serial Correlation } \\
\text { Test }\end{array}$ & $\begin{array}{c}\text { Heteroscedastity } \\
\text { Test }\end{array}$ \\
\hline M1 & $3.92(0.14)$ & $1.70(0.42)$ & $13.09(0.67)$ \\
\hline M2 & $0.24(0.88)$ & $0.26(0.88)$ & $7.85(0.35)$ \\
\hline Private Sector Credit & $2.10(0.35)$ & $6.24(0.4)$ & $9.14(0.82)$ \\
\hline
\end{tabular}

The null hypotheses of residual tests state that errors are normally distributed with no serial correlation and homoscedasticity. The value of parenthesis are greater than 0.05 . These show that null hypothesis cannot be rejected. Hence, conclusion can be drawn as errors are normally 
Dhakal, N. K., \& Timsina, M. P. (2020) Price and output effects of Monetary policy in Low Income Countries: The Case of Nepal. Advances in Social Sciences Research Journal, 7(5) 478-495.

distributed, no serial correlation and constant variance at 5 percent level of significance. However, null of serial correlation exists in model which has private sector credit at 1 percent of p-value.

\section{Stability Test}

The below figures show the stability of models.

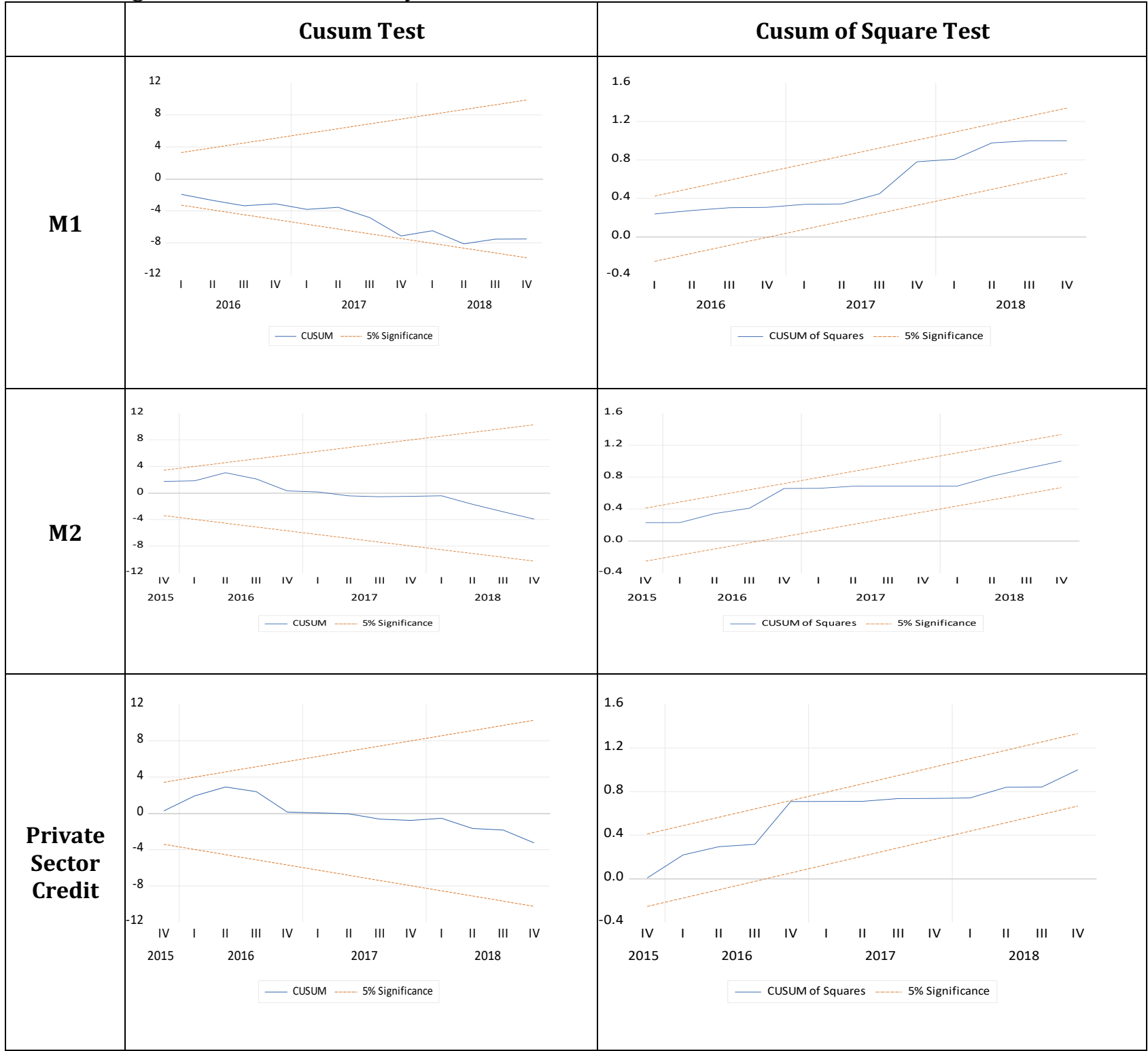

\section{CONCLUSION}

This paper shows the impact of monetary policy on economic growth and inflation in Nepal. It has used quarterly data of economic growth, inflation rate, CRR, bank rate, interbank rate, money supply, broad money and private sector credit ranging from first quarter of 2006 to fourth quarter of 2018. Monetary policy impact on economic growth and inflation rate has been observed separately developing six models. The study uses econometric methods like ADF test, ARDL Model, Bound Test, Error Correction Model, Residual Test and Stability test to estimate the results. 
The results show that CRR, bank rate, broad money, private sector credit are significant to have impact on economic growth. Likewise, money supply has impact on inflation. The result shows that it takes longer time to have impact on broad money and private sector credit on economic growth than on inflation.

\section{References}

[1] Mishkin, F. S. Symposium on the monetary transmission mechanism, 1995. The Journal of Economic Perspectives 9 (4):3-10.

[2] Friedman, B. M., and M., Woodford. Hand book of monetary economics, 2010. London: Elsevier.

[3] Mishra, P., P. J. Montiel, and A. Spilimbergo, Monetary transmission in low income countries, 2010. IMF Working Papers 10/223. Washington DC: International Monetary Fund.

[4] Walsh, C.E., Monetary Theory and Monetary Policy (Third Edition), 2010. MIT Press, Cambridge, Massachusetts.

[5] Issing, O., Why Price Stability?, 2000. Proceedings of First ECB Central Banking Conference.

[6] Mohanty, D., Evidence of Interest Rate Channel of Monetary Policy Transmission in India, 2012. Reserve Bank Working Paper Series, Reserve Bank of India.

[7] Vonnak, B., Estimating the effect of Hungarian monetary policy within a structural VAR framework, 2005. MNB Working Papers, No. 2005/1. Magyar Nemzeti Bank, Budapest.

[8] Choudhri E.U., Jan, A. and Malik H, Monetary Policy in Pakistan: Effectiveness in [3] Inflation Control and Stabilization, 2015. International Growth Centre. London School of Economic and Political Science, Houghton Street, London,

[9] Younus, S., Effectiveness of Monetary Transmission Channels in Bangladesh: Evidence from a Floating Exchange Rate Regime, n.d.. Working Paper Series: WP No 1607 Research Department, Bangladesh Bank.

[10] Vinayagathasan, T,. Monetary Policy and the Real Economy: A Structural VAR Approach for Sri Lanka, 2013. GRIPS Discussion Paper 13-13. National Graduate Institute for Policy Studies. Tokyo, Japan.

[11] NRB, Money and Price Relationship in Nepal: A Revisit, 2001. NRB Economic Review, Vol. 13, Research Department, Nepal Rastra Bank

[12] Khatiwada, Y. R., Monetary Policy. NRB in 50 Years, 2005. Golden Jubilee Publication: 279-295. Nepal Rastra Bank, Kathmandu.

[13] IMF., Nepal: 2014 Article IV Consultation-Staff Report. IMF Country Report No. 14/214, 2014. Washington, D.C. : International Monetary Fund.

[14] Shrestha, M.B. and Bhatta, G.R., Revisiting Money-Price Relationship in Nepal Following a New Methodological Framework, 2018. Economic Review Volume 30-1 Nepal Rastra Bank

[15] MoF. Various Economic Survey. Government of Nepal, Ministry of Finance

[16] NRB, Sixty Years of Nepal Rastra Bank, 2018. Nepal Rastra Bank

[17] NRB. (2019).Collection of Monetary Policy (Part I), Research Department, Nepal Rastra Bank

[18] CBS, Quarterly GDP, 2018. Central Bureau of Statistics Nepal, Retrieved on 13th April, 2020 from :

https://cbs.gov.np/quaterly-gdp-2018/

[19] IHS Global Inc., EViews 8.1 User's Guide, 2014. Retrived on May 20, 2020 at

IIhttp://www.eviews.com/EViews8/EViews8/EViews\%208\%20Users\%20Guide\%20II.pdf\#M23.9.UnitRootTests 